\title{
Tourmaline as a petrogenetic monitor of the origin of the Nyalam pegmatites, South Tibetan Himalaya: In situ chemical and boron isotopic studies
}

\author{
SHUI-YUAN YANG*, SHAO-YONG JIANG
}

State Key Laboratory of Geological Processes and Mineral Resources, China University of Geosciences, Wuhan 430074, PR China

(*correspondene: shuiyuanyang@cug.edu.cn)

Late Oligocene-Miocene leucogranites in the High Himalayan are usually accompanied by tourmaline-bearing pegmatitic dikes. Whether the origin of these pegmatitic dikes can be interpreted as differentiated from the melts of leucogranites or formed from direct crustal anatexis is unclear. In this study, tourmaline-bearing pegmatitic dikes from the Nyalam pegmatitic dikes in South Tibetan Himalaya were selected, and the textural, chemical and B-isotopic compositions of tourmalines were studied to investigate the origin and evolution of the pegmatites. Four distinct textural types (types I IV) of dikes based on the occurrences of tourmaline were selected to study. These tourmaline grains belong to the alkali group, and also belong to the schorl-dravite solid solution series and the schorl-foitite solid solution series. Boron isotopic fractionation modelling suggest that the $2 \mathrm{mg}$ melt have to crystallized approximately $99 \%$ of their boron in the form of tourmaline prior to expulsion of the pegmatitic melts which crystallized the types I, II, and III tourmalines (which has $\delta{ }^{11} \mathrm{~B}$ values between $-13 \%$ and $-12 \% 0$ ), and $>99.99 \%$ for the type IV tourmalines (which has $\delta{ }^{11} \mathrm{~B}$ values of $\sim-8 \%$ ), which would leave essentially no boron for the formation of any tourmaline in the expulsion of the pegmatitic melts. Thus, the Nyalam pegmatites cannot be differentiated from the melts of $2 \mathrm{mg}$. Based on these B-isotopic data, we suggest that the Nyalam pegmatites were formed by direct crustal anatexis. 